\title{
Comparative Analysis of Heat Resistance of Ornamental Urban Plants in Kyiv
}

\section{Oleksandra Strashok}

1 National University of Life and Environmental Sciences of Ukraine, 03041, Heroiv Oborony st. 15, Kyiv, Ukraine E-mail: landscape-architecture@nubip.edu.ua

\begin{abstract}
Urban plants play a significant role in shaping the microclimate of the modern city, in addition to the recreational and aesthetic functions. Climate change and sharp changes in temperature affect the plant growth and development, so the question of studying the adaptive potential of the plant range in cities to temperature variability is relevant and important. Researchers and scientists around the world are studying the impact of biotic and abiotic factors on plants, but the variability of the plant organisms in the urban ecosystem is still unexplored. The data from the analysis of the frequency of occurrence plants in Kyiv green spaces show that Tilia cordata Mill., Aesculus hippocastanum L., Spiraea $\times$ vanhouttei (Briot) Zabel. and Carpinus betulus L. are most represented among the researched species. The article presents the results of the assessment of heat resistance by using the method of Matskov (1976) of 13 ornamental woody and shrubby species. Besides, the plants were separated into groups of tolerance to high temperatures. It was established that the $T$. cordata plants are characterized by the highest indicators of heat tolerance and they can be recommended for the creation of open landscapes. The A. hippocastanum, Catalpa bignonioides Walt., S. vanhouttei and Forsythia europaea Degen \& Bald. plants are characterized by 'moderate tolerance' indicators to high temperature stress, therefore they can be recommended for the creation of semi-open/open landscape types. Consequently, for the formation of semi-open landscapes, using the species Platanus occidentalis L., Quercus robur L., Q. rubra, Syringa vulgaris L., Berberis thunbergii DC. and Ligustrum vulgare L. which were assessed as 'moderately sensitive', is recommended. The leaves of the Carpinus betulus L. and Ribes aureum Pursh. plants were most vulnerable to high temperature stress; therefore, the species are recommended for the formation of closed landscape types. Despite the comparative classification of ornamental plants in terms of heat-resistance, many issues remain unstudied and need to be clarified in terms of ecology, physiology, biochemistry and phytopathology for the plants of urban green spaces.
\end{abstract}

Keywords: abiotic stress, green space, landscape type, necrosis, temperature.

\section{INTRODUCTION}

According to NASA, the average temperature of the Earth's surface has risen by approx. 1.18 ${ }^{\circ} \mathrm{C}$ since the end of the 19th century and the last 7 years were the warmest in human history. Besides, the IPCC predicted an increase of temperature in the range of $2-3^{\circ} \mathrm{C}$ over the next $30-50$ years (IPCC 2007). It is widely recognized in literature that the "urban heat island" (UHI) forms in the cities where the surface and air temperatures are higher than the temperature outside. The UHI can vary in density, size and location depending on many factors that can cause temperatures to rise from 1 to $6^{\circ} \mathrm{C}$ (US EPA 2008). Researchers noted that the UHI causes water loss in plants and primarily affects the leaf blades (Trownbridge \& Bassuk 2004). It should be noted that high temperatures have a negative impact not only on urban plants but also on human well-being (Kleerekoper et al. 2012, Matzarakis \& Amelung 2008). The high-temperature stress has an indirect effect on plant ontogenesis and is characterized by morphological, physiological, biochemical and molecular changes in the plant organism.

The modern city is a complex of dynamic system that develops under the conditions of abiotic stress and anthropogenic load. At the beginning 
of the $21^{\text {st }}$ century, Ukrainian scientists noted that the annual air temperature has risen by $0.8^{\circ} \mathrm{C}$ on the territory of Ukraine over the past 20 years and continues to rise (Barabash 2004, Adamenko 2007). Moreover, over the past 10 years in the southern part of Ukraine, the annual rainfall has decreased and the temperature has risen by $2.0^{\circ} \mathrm{C}$ which may contribute to the desertification of the territory (Vozhegova et al. 2021). Plant growth and development is accompanied by fluctuations in temperature naturally but extreme temperatures in the hot season can damage intermolecular bonds and change their course (Christensen $\&$ Christensen 2007). Indicators of temperature and vegetation period of plants are closely correlated with each other. The ability to maintain gas exchange of leaves during heat stress is directly correlated with heat resistance in all plant species (Salvucci \& Crafts-Brandner 2004). One of the typical symptoms of heat stress is tissue aging which is characterized by membrane damage associated with increased membrane lipid fluidity, lipid peroxidation and protein degradation in various metabolic processes (Savchenko et al.
2002). Researchers noted that the average length of the growing season in the cities is $\sim 5$ days longer than in the surrounding rural areas due to the urban thermal island (Zipper et al. 2016). On the one hand, urban plants represent the adaptation option to the impacts of climate change and on the other hand, healthy vegetation has the highest economic, social and microclimatic benefit (Gillner et al. 2014). Summing up all the above, it is necessary to create green spaces from the species with high adaptive potential to climate changes for forming a comfortable microclimate in cities for residents' well-being.

\section{MATHERIALS AND METHODS}

The aim of the research work was selection and classification ornamental urban plant species by indicators of heat resistance for green spaces in Kyiv. The samples for the experiment were taken from the plants which grow on the territory of the National University of Life and Environmental Sciences of Ukraine in 2019. All experimental

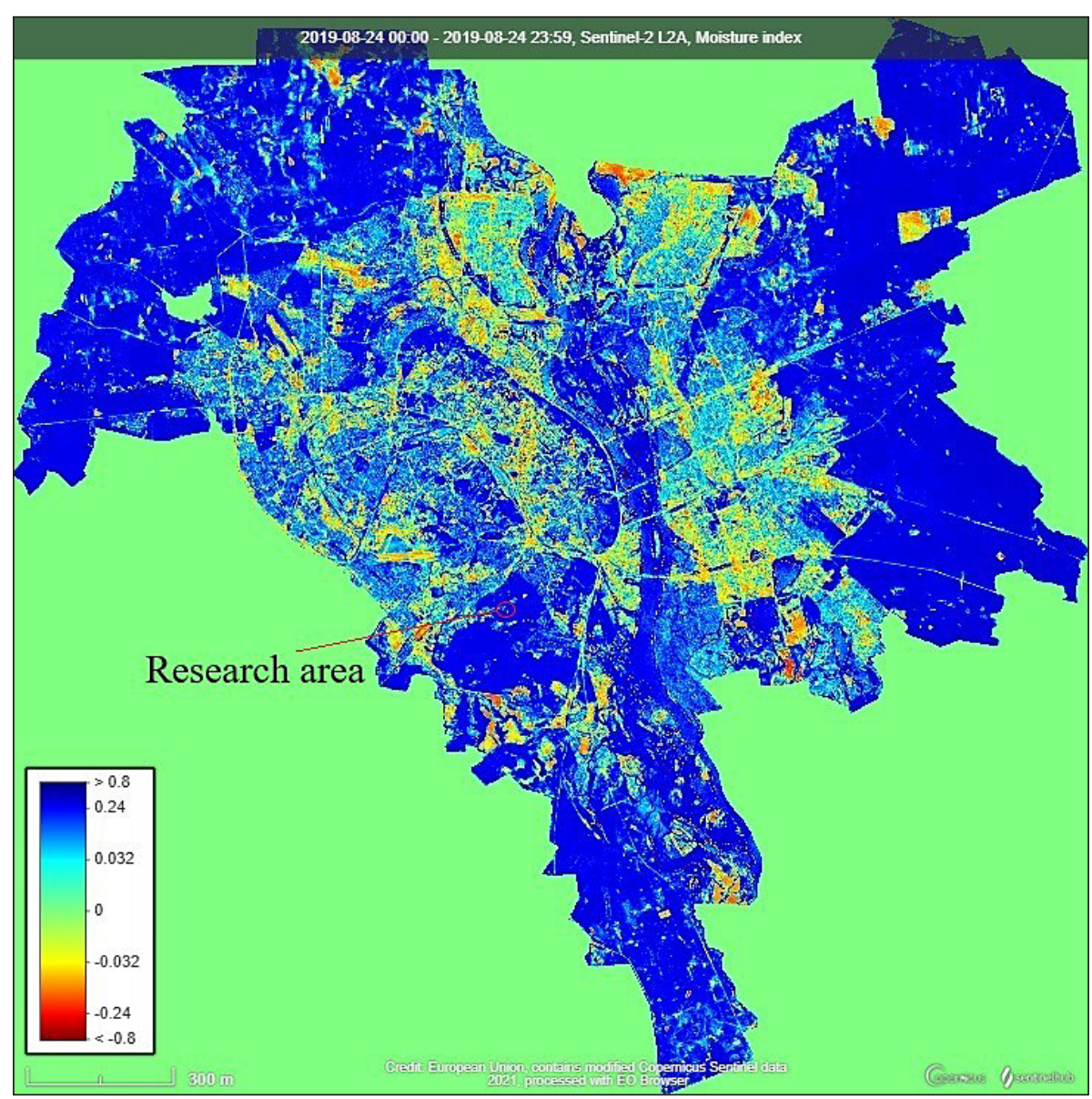

Figure 1. Map of Normalized Difference Moisture Index in Kyiv (Sentinel-2; 2019-08-24) 


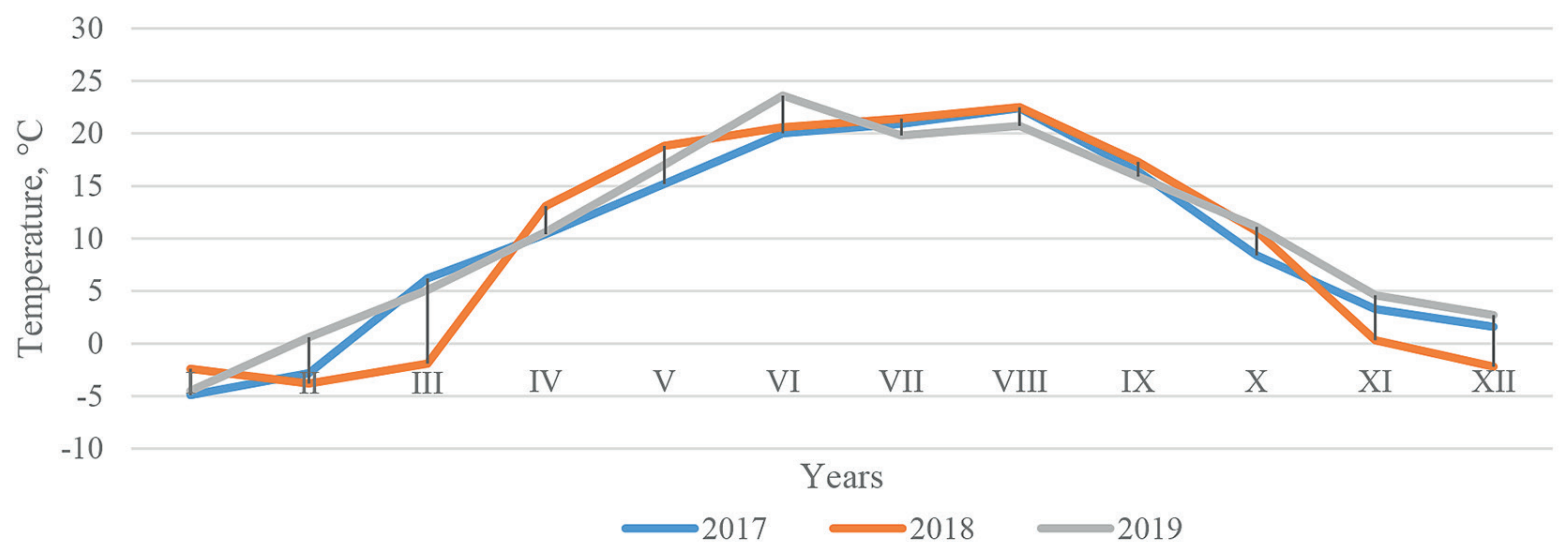

Figure 2. Average monthly temperatures in Kyiv in the period from 2017 to 2019 (Central Geophysical Observatory named after Boris Sreznevsky)

plants were healthy and undamaged. In the year of sampling, the Normalized Difference Moisture Index also indicates a sufficient amount of moisture for the plants at the research site (Fig. 1). The map shows the location of experimental plants in Kyiv and indicators Normalized Difference Moisture Index in August 2019.

The official data of Central Geophysical Observatory named after Boris Sreznevsky were used to analyze the temperature in Kyiv. Indicators of average monthly temperatures for the last 3 years in Kyiv indicate an increase in air temperature in winter. In addition, in 2019 when samples were collected, the temperature in June was the highest compared to previous years, while in July-August it was the lowest (Fig. 2).

The plants grow in different types of ornamental plantings (solitaire, line or group planting) (Fig. 3ad). Plants grow 1-10 m directly from the highway.

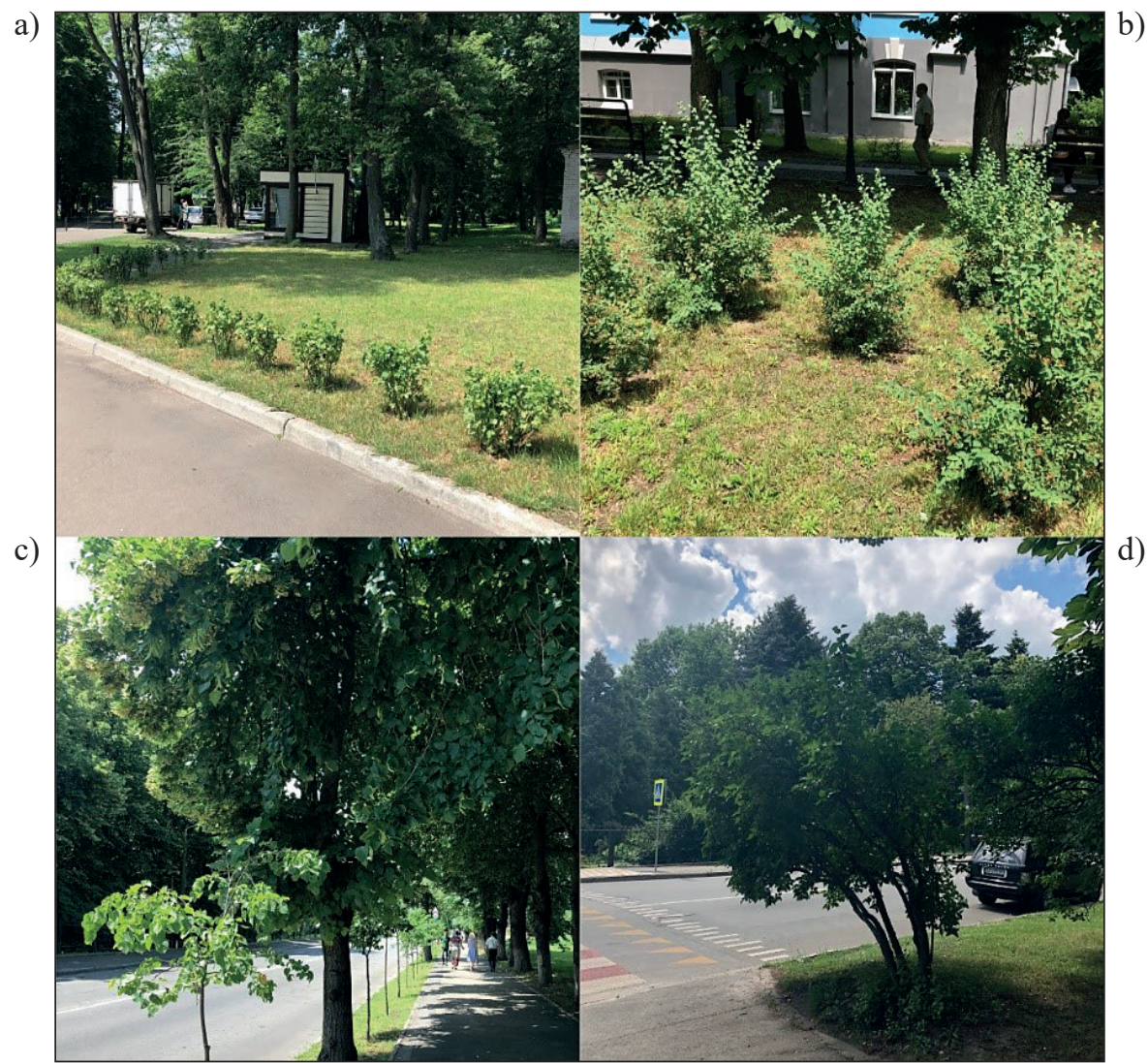

Figure 3. Experimental plants: a - Ribes aureum Pursh (line planting); $\mathrm{b}-$ Spiraea $\times$ vanhouttei (Briot) Zabel. (group); c - Tilia cordata Mill. (line planting, avenue); $\mathrm{d}-$ Syringa vulgaris L. (solitaire) 
The systematic position of plants and the nomenclature of taxa were determined by the Plant List. The official data of the Register of urban beautification of Kyiv (2019) were used to estimate the frequency of occurrence of the species and assess the following indicators: $\mathrm{SNG}-$ the species occurs singly (1-3 places of growth); OCNL (occasionally) - noted sometimes (4-10 places of growth); OFT (often) - noted frequently (11-25 places of growth); M (mass) - the species occurs masse (> 25 places of growth) (Potapenko, 2010).

Heat resistance was evaluated using the method of Matskov (1976) in June, July, August 2019. Leaves were immersed for 30 minutes in a water bath with the initial temperature $+40^{\circ} \mathrm{C}$ and transferred to the crystallizer with water at room temperature. Subsequently, the temperature of the water bath was raised gradually by $10^{\circ} \mathrm{C}$ and after each 10 minutes. The water in the crystallizer was replaced with $0.2 \mathrm{~N} \mathrm{HCl}$ and after $20 \mathrm{~min}$ results were obtained. The membranes destroyed by the high temperature passed the acid and lost their selective properties which due to the chlorophyll pheophytinization caused browning of the plates. The experiment was stopped at $90^{\circ} \mathrm{C}$ (lethal level). The degree of heat resistance was determined by the proportion of brownish tissues of the leaf blade on a three-point scale. The plants with minimal damage to the leaf surface were rated 1 point $(+), 2$ points $(++)-50 \%$ and 3 points $(+++)-100 \%$ damage.

Three categories of landscape openness were distinguished according to the classification of Rodichkin (1972): A - the landscape of closed spaces (closed); B - landscape of semiopen spaces (semi-open); C - landscape of open spaces (open).

\section{RESULTS AND DISCUSSION}

The results of the analysis of average annual temperatures for the last 10 years in Kyiv show an increase on $1.7^{\circ} \mathrm{C}$ that indicates climate change and variability of the thermal sum for plants (Fig. 4). It should be noted that in 2019 the winter was the warmest of all years in Kyiv. According to Central Geophysical Observatory named after Boris Sreznevsky in 2019 were more than 30 temperature records. Researchers Jerry L. Hatfield \& John H. Prueger (2015) noted that there is a greater chance of air temperatures exceeding the optimum range for many plant species due climate changes. Therefore, the study of potential changes in the growth and development of urban plants will help to form stable long-term plantings in urban spaces.

The first stage of the conducted research was analysis of plant ranges of green spaces of different types of use in Kyiv by frequency of occurrence. The experimental plants are characterized by different indicators of occurrence in the landscaping system in Kyiv (Table 1). Thus, among the plants selected for research, the most represented in green spaces are Tilia cordata Mill., Aesculus hippocastanum L., Spiraea $\times$ vanhouttei (Briot) Zabel. and Carpinus betulus L. Despite the fact that the Catalpa bignonioides Walt. plants also evaluated in terms of the frequency of occurrence "mass", it should be noted that they are about in 10 times less numerous than $T$. cordata presented in different types of plantations. It was determined that the species Syringa vulgaris L. and Forsythia europaea Degen \& Bald. are "often" found in the landscaping system of Kyiv and the Berberis thunbergii DC. and Ligustrum vulgare L. plants are mainly found in newly created landscaping objects and rated "sometimes".

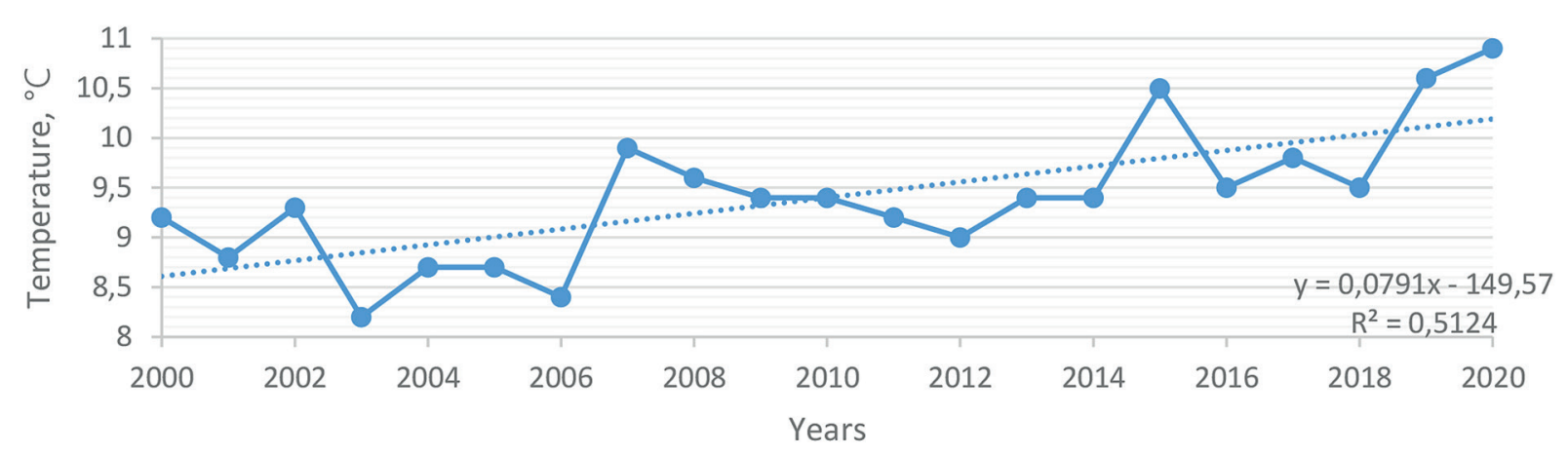

Figure 4. Average annual temperatures in Kyiv in the period from 2017 to 2019 (Central Geophysical Observatory named after Boris Sreznevsky) 
Table 1. Frequency of species occurrence in plantations of different functional purpose on the territory of Kyiv

\begin{tabular}{|c|l|c|l|c|}
\hline No. & \multicolumn{1}{|c|}{ Botanical name } & Family & \multicolumn{1}{|c|}{ Type of planting } & Frequency of species occurrence \\
\hline 1 & Aesculus hippocastanum L. & Fagaceae & Solitaire, lines, avenue & M \\
\hline 2 & Carpinus betulus L. & Betulaceae & Hedge, solitaire & M \\
\hline 3 & Catalpa bignonioides Walt. & Bignoniaceae & Solitaire, group, avenue & M \\
\hline 4 & Platanus occidentalis L. & Platanaceae & Solitaire & SNG \\
\hline 5 & Quercus robur L. & Fagaceae & Line, avenue, solitaire & SNG \\
\hline 6 & Quercus rubra L. & Fagaceae & Solitaire, line group & M \\
\hline 7 & Tilia cordata Mill. & Tilliacea & $\begin{array}{l}\text { Line, avenue, group, } \\
\text { solitaire }\end{array}$ & OCNL \\
\hline 8 & Berberis thunbergii DC. & Berberidaceae & Group, hedge & OCNL \\
\hline 9 & Ligustrum vulgare L. & Oleaceae & Hedge, group & OFT \\
\hline 10 & Syringa vulgaris L. & Oleaceae & Solitaire, group & SNG \\
\hline 11 & Ribes aureum Pursh. & Grossulariaceae & Hedge, group & M \\
\hline 12 & Spiraea $\times$ vanhouttei (Briot) Zabel. & Rosaceae & Group, line, hedge & OFT \\
\hline 13 & Forsythia europaea Degen \& Bald. & Oleaceae & Solitaire, group, line & \\
\hline
\end{tabular}

The experimental study was aimed to analyze and select the heat resistance of ornamental plant species for predicting their future adaptation to the conditions of global climate change. Using the method of Matskov (1976) plants were divided by the degree of necrotization of the leaf blade to high temperature stress. Thus, only one species among the experimental plants $T$. cordata was characterized by the highest indicators of tolerance to thermal stress (Fig. 2).
However, in authors' opinion, other species of ornamental plants with the leaf blades where the process of necrotization took place completely at lower temperatures are also quite promising for green spaces of the modern city for arid climate. It should be remembered that under natural conditions, the heating of the plant does not reach the same temperature as in the laboratory conditions in this research (Table 2). The reaction of rate of color change in different species at various temperatures
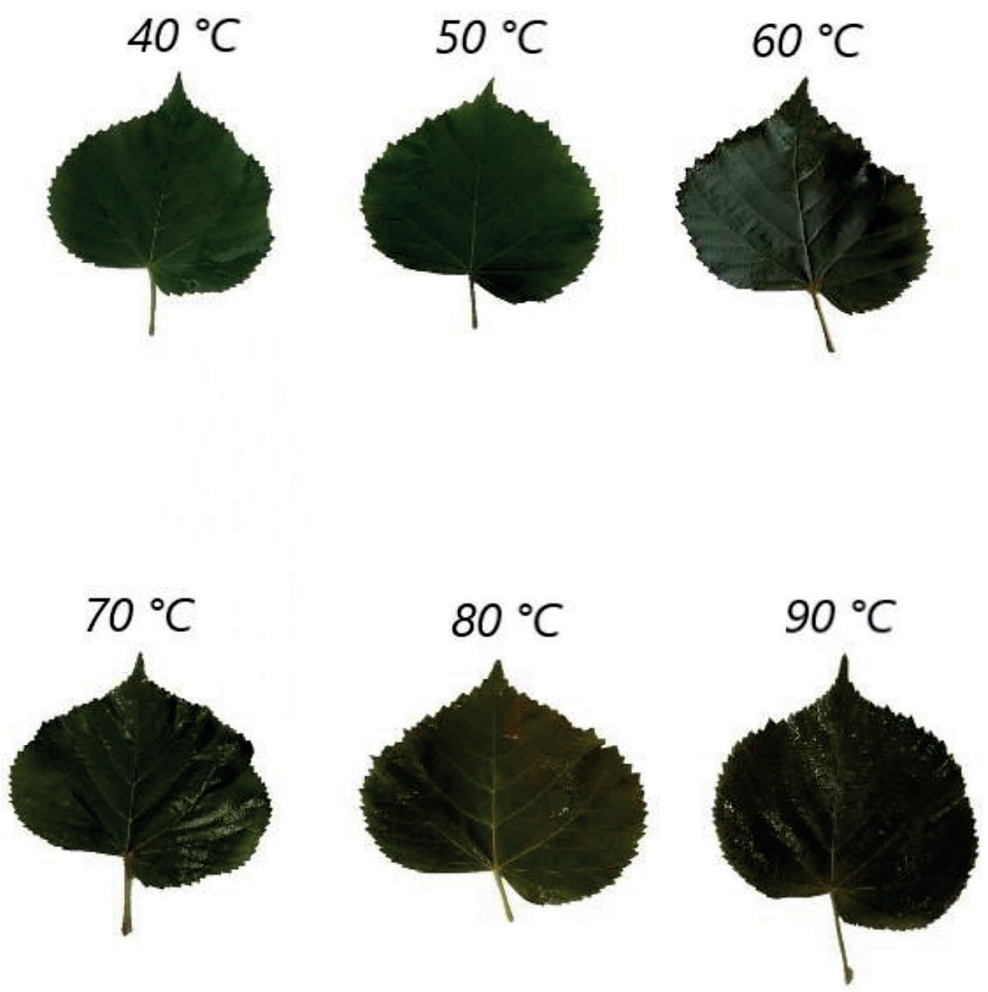

Figure 5. Discoloration and necrotization of the leaf blade of Tilia cordata Mill. under high temperatures 
Table 2. Heat resistance of ornamental urban plants

\begin{tabular}{|l|c|c|c|c|c|c|}
\hline \multirow{2}{*}{ Botanical name } & \multicolumn{2}{|l}{ Degree of damage at temperature, C } & \multicolumn{2}{l|}{} \\
\cline { 2 - 7 } & 40 & 50 & 60 & 70 & 80 & 90 \\
\hline Low damage & - & + & ++ & ++ & 0 & $\begin{array}{c}\text { high } \\
\text { damage }\end{array}$ \\
\hline Aesculus hippocastanum L. & - & + & ++ & ++ & +++ & 0 \\
\hline Carpinus betulus L. & - & + & +++ & 0 & 0 & 0 \\
\hline Catalpa bignonioides Walt. & - & + & ++ & ++ & +++ & 0 \\
\hline Platanus occidentalis L. & - & + & ++ & +++ & 0 & 0 \\
\hline Tilia cordata Mill. & - & - & + & + & ++ & +++ \\
\hline Quercus robur L. & - & - & ++ & +++ & 0 & 0 \\
\hline Quercus rubra L. & - & - & ++ & +++ & 0 & 0 \\
\hline Syringa vulgaris L. & - & - & ++ & +++ & 0 & 0 \\
\hline Berberis thunbergii DC. & - & - & ++ & +++ & 0 & 0 \\
\hline Spiraea×vanhouttei (Briot) Zabel. & - & - & + & ++ & +++ & 0 \\
\hline Ligustrum vulgare L. & - & - & ++ & +++ & 0 & 0 \\
\hline Ribes aureum Pursh & - & - & +++ & 0 & 0 & 0 \\
\hline Forsythia europaea Degen \& Bald. & - & - & + & ++ & +++ & 0 \\
\hline
\end{tabular}

is explained by the influence of high temperatures on the conformation of membrane proteins which creates the preconditions for their anomalous aggregation. Thus, maintaining the selectivity of the membranes provides effective protection of the lamellae from the destructive action of hydrochloric acid, which converts chlorophyll molecules into pheophytin, which causes browning of the leaf blade (Leshchenko 2014, Popovych et al. 2021).

Thus, the results of the conducted research are partially consistent with the data of other scientists where A. hippocastanum is rated as 'moderately tolerant'. The trees were divided by heat tolerance in the following sequence: 'very tolerant' (Betula pendula Roth., Fraxinus excelsior L.), 'moderately tolerant' (A. hippocastanum, Acer platanoides L., Q. robur), and 'moderately sensitive' (Acer pseudoplatanus L., Fagus sylvatica L.) (Brune 2016).

The results show that the leaf blades of the C. bignonioides plants are characterized by high indicators of resistance to high temperature stress. The full-fledged necrotization occurred at

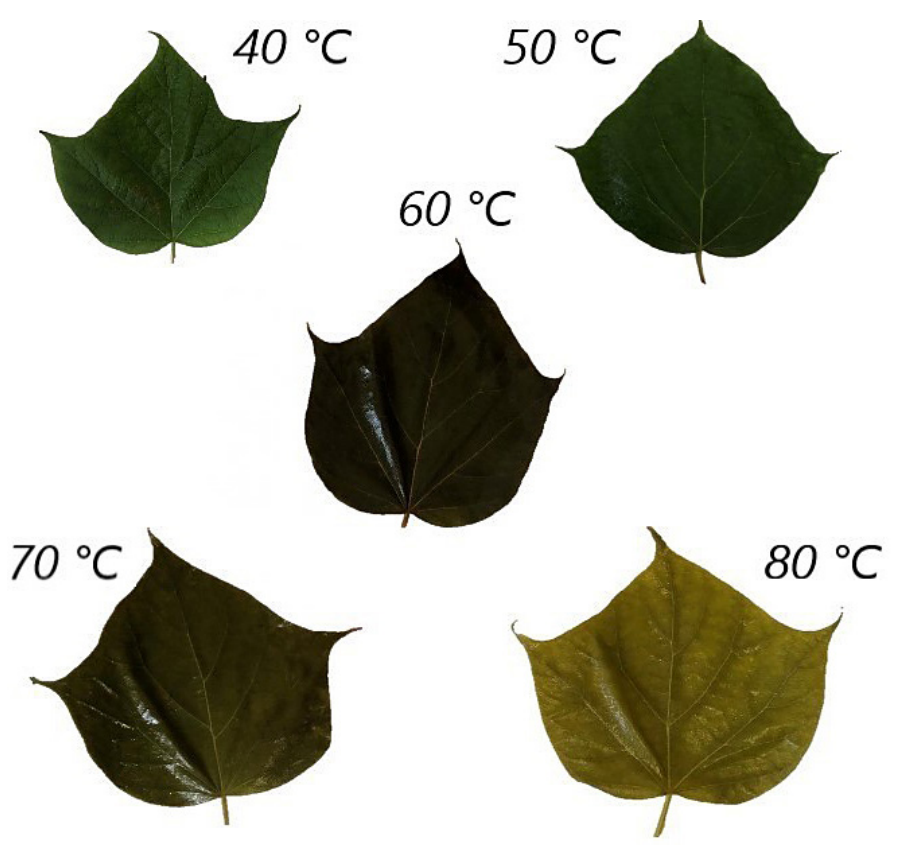

Figure 6. Discoloration and necrotization of the leaf blade of Catalpa bignonioides Walt. under high temperatures 
a temperature of $80^{\circ} \mathrm{C}$ which indicates the prospects for expanding the use of the species in the landscaping system of the city.

In addition, the results of research allow classifying ornamental plant species according to the degree of resistance to high temperature stress and distinguishing them into tolerance classes: 'sensitive' - necrotization of the leaf blade occurs at a temperature $60^{\circ} \mathrm{C}$; 'moderately sensitive'- necrotization of the leaf blade occurs at a temperature $70^{\circ} \mathrm{C}$; 'moderately tolerant' - necrotization of the leaf blade occurs at a temperature $80^{\circ} \mathrm{C}$; 'very tolerant' - necrotization of the leaf blade occurs at a temperature $90^{\circ} \mathrm{C}$ (Table 3).

It is well known that in the crown of trees the temperature regime within the crown differs from the environment and is characterized by a specific microclimate. Moreover, forming a range of plants to create different types of landscapes on the basis of indicators of tolerance to high-temperature stress was proposed; this will allow creating highly decorative long-term decorative plantings (see Table 3). Researchers Jing Wang \& Wei Guo (2021) found that increasing the ratio of the radius of the crown to the height of the trunk by 1 can reduce the physiologically equivalent temperature by about $2.5^{\circ} \mathrm{C}$ and $2.65^{\circ} \mathrm{C}$ in the morning and afternoon, respectively. Thus, due to the layering of leaf blades, reducing the fluxes of photons of light and heat, transpiration and gas exchange processes, the temperature in the crown decreases to the lower tiers and forms different microclimate from the external environment (Gonzalez-Dugoa et al. 2011; Camino et al. 2018, Pui Kwan Cheung \& Jim 2018) (Fig.7). Therefore, it can be assumed that the species less tolerant to high temperature stress should be planted in closed types of landscapes and tolerant in open, respectively.

Thus, the T. cordata species have the highest indices of tolerances to high temperature stress and are rated as 'very tolerant'; they can be recommended for the formation of open landscape types where the closure of the crowns is not more than 0.1 . The species $A$. hippocastanum, $C$.

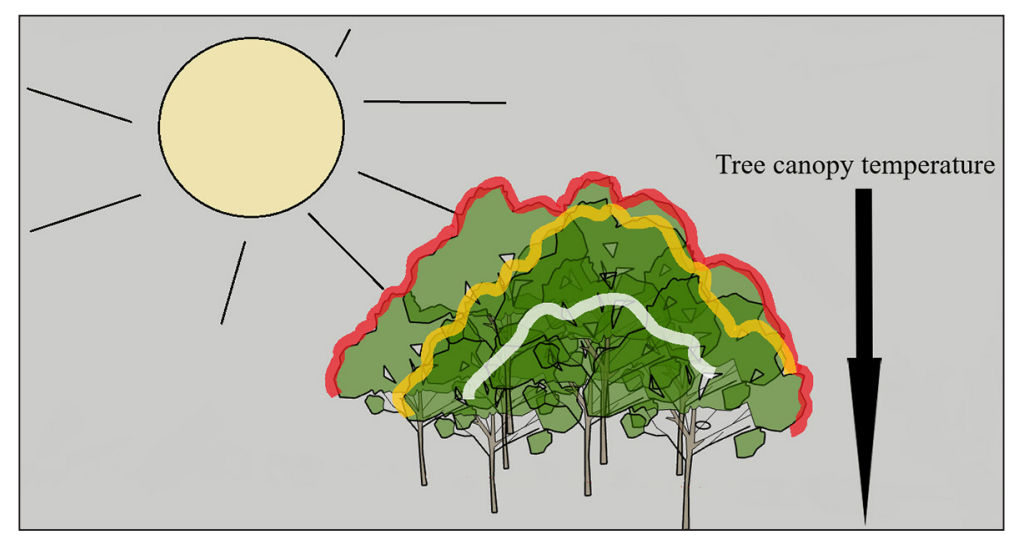

Figure 7. Illustration of forming tree canopy temperature in close type of landscape

Table 3. Tolerance of ornamental species to high temperature stress and recommended landscape types

\begin{tabular}{|l|c|c|}
\hline \multicolumn{1}{|c|}{ Botanical name } & Heat stress tolerance & Landscape openness \\
\hline Aesculus hippocastanum L. & moderately tolerant & semi-open/open \\
\hline Carpinus betulus L. & sensitive & closed \\
\hline Catalpa bignonioides Walt. & moderately tolerant & semi-open/open \\
\hline Platanus occidentalis L. & moderately sensitive & open \\
\hline Tilia cordata Mill. & very tolerant & semi-open \\
\hline Quercus robur L. & moderately sensitive & semi-open \\
\hline Quercus rubra L. & moderately sensitive & semi-open \\
\hline Syringa vulgaris L. & moderately sensitive & semi-open/open \\
\hline Berberis thunbergii DC. & moderately sensitive & semi-open \\
\hline Spiraea×vanhouttei (Briot) Zabel. & moderately tolerant & closed \\
\hline Ligustrum vulgare L. & moderately sensitive & semi-open/open \\
\hline Ribes aureum Pursh & sensitive & moderately tolerant \\
\hline Forsythia europaea Degen \& Bald. &
\end{tabular}


bignonioides, S. vanhouttei and F. europaea were rated as 'moderately tolerant' and these plants can be recommend for creation semi-open/open landscape types. Accordingly, the use of Platanus occidentalis L., Q. robur, Q. rubra, S. vulgaris, $B$. thunbergii and $L$. vulgare can be recommended for the formation of semi-open landscapes which were assessed as 'moderately sensitive'.

Semi-open spaces are usually characterized by group and single plantings which will reduce the impact of high-temperature stress on plants due to higher crown closure compared to open. Since, the leaf blades of $C$. betulus and $R$. aureum were most vulnerable to high temperature stress, plant species are recommended for the formation of closed types of landscapes with a crown closure of 0.6-1.0.

\section{CONCLUSIONS}

The high-temperature stress has an indirect effect on plant ontogenesis. The results of experimental studies allow identifying heat resistant plant species for the formation of urban green spaces under conditions of arid climate. The $T$. cordata plants are characterized by the highest indicators of heat tolerance and probably have the highest adaptive potential for heat stress, but the issue needs further study. Species A. hippocastanum, C. bignonioides, $S$. vanhouttei and F. europaea are recommended for landscaping of Kyiv for semiopen/open landscape types and were rated by indicator 'moderately tolerant', the species $P$. occidentalis, Q. robur, Q. rubra, S. vulgaris, B. thunbergii and $L$. vulgare which were assessed as 'moderately sensitive' to heat stress can be recommended for the formation of semi-open landscapes. The leaf blades of $C$. betulus and $R$. aureum were most vulnerable to high temperature stress; therefore, the species are recommended for use in the formation of closed landscape types. In authors' opinion, the distribution of the range of plants according to indicators of tolerance to high temperature stress will be useful for the landscape architects creating green spaces from heat-resistant plants. However, the adaptation mechanisms of urban plants to heat stress remains unexplored and need clarification.

\section{REFERENCES}

1. Adamenko T.V. 2007. Klimatychni umovy Ukrainy ta mozhlyvi naslidky poteplinnia klimatu. Ahronom, 1, 8-9.
2. Barabash M.O., Kulbida M.V., Korzh T.I. 2004. Zmina hlobalnoho klimatu i problema opusteliuvannia Ukrainy. Naukovi zapysky Ternopilskoho DHP, 2, 82-88.

3. Bita Craita E., Gerats T. 2013. Plant tolerance to high temperature in a changing environment: scientific fundamentals and production of heat stresstolerant crops. J. Frontiers in Plant Science. 4, 273 https://doi.org/10.3389/fpls.2013.00273

4. Brune M. 2016. Urban trees under climate change. Potential impacts of dry spells and heat waves in three German regions in the 2050s. Report 24. Climate Service Center Germany, Hamburg.

5. Camino C., Zarco-Tejada P.J., González-Dugo V. 2018. Effects of Heterogeneity within Tree Crowns on Airborne-Quantified SIF and the CWSI as Indicators of Water Stress in the Context of Precision Agriculture. Remote. Sens., 10, 604.

6. Central Geophysical Observatory named after Boris Sreznevsky Retrieved from: http://cgo-sreznevskyi. kyiv.ua/index.php? $\mathrm{fn}=\mathrm{k} \_$klimat\&f=kyiv

7. Christensen J.H., Christensen O.B. 2007. A summary of the PRUDENCE model projections of changes in European climate by the end of this century. Clim. Change 81, 7-30. https://doi.org/10.1007/ s10584-006-9210-7

8. Gillner S., Bräuning A., Roloff A. 2014. Gillner, S., Bräuning, A., \& Roloff, A. Dendrochronological analysis of urban trees: climatic response and impact of drought on frequently used tree species. Trees, 28, 1079-1093.

9. Gonzalez-Dugoa V., Zarco-Tejadaa P.J., Bernia J.A., Suáreza L., Goldhamerb D., Fereresa E. 2011. Almond tree canopy temperature reveals intra-crown variability that is water stress-dependent. Agricultural and Forest Meteorology 154-155, 156-165. https://doi.org/10.1016/j.agrformet.2011.11.004.

10. Intergovernmental Panel Climate Change (IPCC). 2007. Climate Change 2007: Impacts, Adaptation and Vulnerability: Contribution of Working Group II to the Fourth Assessment Report of the Intergovernmental Panel on Climate Change. Cambridge University Press, Cambridge, U.K. and New York, NY.

11. Hatfield J.L., Prueger J.H. 2015. Temperature extremes: Effect on plant growth and development, Weather and Climate Extremes, 10, 4-10.

12. Wang J., Guo W., Wang C., Yao Y., Kou K., Xian D., Zhang Y. 2021. Tree crown geometry and its performances on human thermal comfort adjustment. Journal of Urban Management, 10(1), 16-26. https://doi.org/10.1016/j.jum.2021.02.001

13. Kleerekoper L., van Esch M., Salcedo T.B. 2012: How to make a city climate-proof, addressing the urban heat island effect. Resources, Conservation and Recycling, 64, 30-38.

14. Leshchenko O.I., Kolesnichenko O.V., Likhanov A.F. 2015. Diahnostyka zharostiikosti roslyn 
Lolium perenne L. vitchyznianoi selektsii. Lisove i sadovo-parkove hospodarstvo http://journals.nubip. edu.ua/index.php/Lis/article/view/9978/8878

15. Matskov F.F. 1976. Raspoznavanye zhyvыkh, mertvыkh y povrezhdennыkh khlorofyllonosnыkh tkanei rastenyi po reaktsyy obrazovanyia feofetyna pry otsenke ustoichyvosty k эkstremalnыm vozdeistvyiam. Metodы otsenky ustoichyvosty rastenyi k neblahopryiatnыm uslovyiam sredы, L.: Kolos, S. 54-60.

16. Matzarakis A., Amelung B. 2008. Physiological Equivalent Temperature as Indicator for Impacts of Climate Change on Thermal Comfort of Humans. In: M. C. Thomson, R. Garcia-Herrera, \& M. Beniston (eds.): Seasonal Forecasts, Climatic Change and Human Health. New York: Springer, 161-172.

17. NASA. Retrieved from https:/climate.nasa.gov/ evidence/

18. Plant List. Retrieved from http://www.theplantlist.org/

19. Popovych V., Stepova K., Telak O., Telak, J. 2021. Heat Resistance of Landfill Vegetation. Journal of Ecological Engineering, 22(1), 267-273. https://doi. org/10.12911/22998993/130022

20. Potapenko Y.L. 2010. Drevesnыe rastenyia aboryhennoi florы v zelenom stroytelstve Vostochnoho raiona Yuzhnoho bereha Кrыma. Эkosystemы, ykh optymyzatsyia y okhrana, 2, 30-41.

21. Pui Kwan Cheung, C.Y. Jim. 2018. Comparing the cooling effects of a tree and a concrete shelter using PET and UTCI, Building and Environment, 130, 4961 https://doi.org/10.1016/j.buildenv.2017.12.013.
22. Rodychkyn Y.D. 1972. Stroytelstvo lesoparkov. SSSR, M.: Yzd-vo "Lesn. prom-st".

23. Salvucci M.E., Crafts-Brandner S.J. 2004. Inhibition of photosynthesis by heat stress: the activation state of Rubisco as a limiting factor in photosynthesis. Physiol. Plant. 120, 179-186. https://doi.org/10 $.1111 / \mathrm{j} .0031-9317.2004 .0173$

24. Savchenko G., Klyuchareva E., Abramchik L. and Serdyuchenko, E. 2002. Effect of periodic heat shock on the inner membrane system of etioplasts. Russ. J. Plant Physiol. 49, 349-359. https://doi. org/10.1023/A:1015592902659

25. Trownbridge P., Bassuk N. 2004. Trees in the Urban Landscape: Site Assessment, design, and installation. Hoboken, N.J.: John Wiley.

26. U.S. Environmental Protection Agency. 2008. Heat Island Effect. http://www.epa.gov/hiri/ [retrived on 15 July 2008].

27. Vozhehova R.A., Netis I.T, Onufran L.I., Sakhatskyi H.I. 2021. Zmina klimatu ta problema arydyzatsii pivdennoho Stepu Ukrainy. Melioratsiia, Zemlerobstvo, Roslynnytstvo, 7, 16-20 https:/doi. org/10.32848/agrar.innov.2021.7.3

28. Wöhrle R.E., Wöhrle H.J. Bott C. 2017. Basics Designing with Plants, Berlin, Boston: Birkhäuser https://doi.org/10.1515/9783035612882

29. Zipper Samuel C., Schatz J., Singh A., Kucharik, Christopher J., Townsend P.A., Loheide II S.P. 2016. Urban heat island impacts on plant phenology: intra-urban variability and response to land cover Environ. Res. Lett. 11, 054023. https://doi. org/10.1088/1748-9326/11/5/054023 